\title{
Spatiotemporal change detection of carbon storage and sequestration in an arid ecosystem by integrating Google Earth Engine and InVEST (the Jiroft plain, Iran)
}

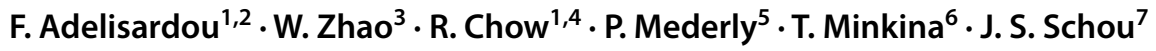

Received: 6 February 2021 / Revised: 25 June 2021 / Accepted: 11 September 2021 / Published online: 25 October 2021

(c) The Author(s) 2021

\begin{abstract}
Our study uses regional-scale maps to quantify carbon storage and sequestration from different land use types to evaluate the effects of future land use scenarios. We developed an integrated modeling approach to assess the spatiotemporal impacts of land use/cover change (LUCC) on the provision and value of the carbon storage and sequestration during the historical period (2000-2019) and predicted scenarios (2019-2046) in the Jiroft plain, Iran. We integrated several analytic tools for our analysis, which was comprised of Google Earth Engine (GEE), Cellular Automata Markov Chain (CA-MC) model, Intensity Analysis (IAA), and the Integrated Valuation of Ecosystem Services and Tradeoffs (InVEST) model. Our results demonstrate that: (1) agriculture and urban expansion led to a considerable decrease in carbon storage, mainly due to rapid deforestation from 2000-2019; (2) if the historical trend continues under the business as usual (BAU) scenario, it will lead to considerable social costs due to the loss of stored carbon in the plain $(2,624,113 \mathrm{Mg})$ with an annual average sequestration loss of $-475,547 \mathrm{Mg}$; (3) the downward carbon sequestration trend could potentially be reversed by employing the environmentally sound planning (ESP) scenario that is estimated to save 3,705,491 Mg in carbon storage, with annual average sequestration gain of $+605,830 \mathrm{Mg}$. The design scenarios provide a useful guide for policymakers and local governments to help understand the potential outcomes of the various development strategies, which will ultimately lead to more effective ecosystem management.
\end{abstract}

Keywords Carbon storage and sequestration · Google Earth Engine · InVEST · Spatial-temporal dynamics · Jiroft plain · Iran

Editorial responsibility: Samareh Mirkia.

F. Adelisardou

Fatemeh.adeli67@ut.ac.ir; Fatemeh.adelisardou@eawag.ch

1 Eawag, Swiss Federal Institute of Aquatic Science and Technology, Dübendorf, Switzerland

2 School of Environment, College of Engineering, University of Tehran, Tehran, Iran

3 Faculty of Geographical Science, Beijing Normal University, Beijing, China

4 Department of Earth Sciences, Stellenbosch University, Stellenbosch, South Africa

5 Department of Ecology and Environmental Sciences, Constantine the Philosopher University in Nitra, Nitra, Slovakia

6 Department of Soil Science, Southern Federal University, Rostov-on-Don, Russia

7 Department of Food and Resource Economics, University of Copenhagen, Copenhagen, Denmark

\section{Introduction}

Ecosystem services (ESs) refer to ecological processes' benefits and their effectiveness for human well-being (Yua et al. 2019). Land use/cover change (LUCC) has a significant impact on the supply and value of multiple ESs, especially climate regulating services, due to fundamental changes that occur in the structure and function of forests, agriculture, and other ecosystems over time (Fu et al. 2017). Such spatiotemporal LUCCs lead to an increase in some services' provision and value while concurrently decreasing others (Yuan et al. 2019), mainly in arid regions (Maestre et al. 2016). As vulnerable ecosystems to human disturbance, these regions cover approximately $40 \%$ of the Earth's land surface (MA 2005). According to White and Nackoney (2003), approximately 1.4 billion Asian people live and depend on drylands. These ecosystems often are regarded as unproductive, but they provide a variety of essential ESs to sustain well-being, 
such as carbon sequestration (Egoh et al. 2016; Lü et al. 2014).

Carbon sequestration describes the long-term carbon storage in soil, plant, and other forms to either mitigate or slow down climatic change (Canadell and Raupach 2008; Eggleston et al., 2006; Gallant et al., 2020). In this context, terrestrial ecosystems, including forest, orchard, and agricultural ecosystems, play an essential role in carbon cycling (Sil et al. 2017). Among terrestrial ecosystems, agriculture often acts as a source of greenhouse gases (Kanime et al. 2013), while forests and orchards are usually involved in the sequestration of atmospheric carbon (Scandellari et al., 2016). Orchards can secure considerable quantities of atmospheric carbon due to their structure, long life cycle, and low or null soil tillage (Ceschia et al. 2010). Forests can also sequester large quantities of atmospheric carbon through photosynthesis (IPCC 2005). The carbon is stored in plant tissues during the photosynthesis of orchards and forests, especially in the woody parts (Hauck et al. 2013). On the other hand, forest and orchard degradation can intensify climate change (Gibbs et al. 2007; Sil et al. 2017). The effect of escalating climate change directly relates to the supply and value of the climate regulating services. De Groot et al. (2012) argued that among the main types of terrestrial biomes (including forests, grasslands, and woodlands), approximately $50 \%$ of their total monetary value is dedicated to climate regulation services.

Various publications of the Intergovernmental Panel on Climate Change (IPCC 2000; 2005; 2006) and the United Nations (UNDP 2015) shed light on the connection between carbon storage and sequestration and LUCC. Recent literature has assessed the climate regulation service by considering their biophysical quantities and economic value, particularly in different arid regions (Bagstad et al. 2013; Crossman et al. 2013; Maes et al. 2016; Sil et al. 2017; Stringer et al. 2012). Many studies have also shown that Iran has experienced impacts of climate change, and this trend continues (Abbaspour et al. 2009; Mansouri Daneshvar et al. 2019). Therefore, anthropogenic disturbance's cumulative effects simultaneously with climate change have significant negative consequences on the ESs, particularly on carbon storage and sequestration. These cumulative effects highlight the importance of providing integrated environmental assessments.

However, in developing countries such as Iran, past modeling and environmental assessments of ESs were limited by the lack of high-quality data (Adelisardou et al. 2021) and appropriate modeling tools. Besides, existing studies concentrate on a specific individual timepoint, ignoring a temporal trend of changes in natural ecosystems and their services (Yavari and Bahreini 2001). There is an urgent need to address the issues mentioned above by considering the dynamics of spatio-temporal impacts of LULC policies on the ESs, such as carbon sequestration and storage for the historical trends and future prediction scenarios.

Various international scientific groups advocated applying the Integrated Valuation of Ecosystem Services and Tradeoffs (InVEST) model as a new generation of ESs assessment model (Keller et al. 2015; Leh et al. 2013; Redhead et al. 2016; Sánchez-Canales et al. 2012). On the other side, carbon storage and sequestration as one of the most common regulating services were quantified and mapped by researchers (Nackoney 2003; Stringer et al. 2012; Kanime et al. 2013; Jiang et al. 2017; Wang and Qie 2018; White, R.P.; Yang et al. 2020). Although various studies of linkage the LUCC with carbon storage and sequestration have been internationally carried out, the target area of studies is mainly focused on cities and coastal ecoregions (Zhao et al. 2016), mountainous regions (Zhao et al. 2018), and flood plains (Lininger et al. 2019). In comparison, InVEST has not been applied to quantify the ES value of carbon sequestration in arid agro-urban ecosystems (Favretto et al. 2016; $\mathrm{Lu}$ et al. 2018). Current research to estimate and predict the change level of carbon considered four carbon pools, including aboveground biomass, belowground biomass, soil organic carbon, and dead organic matter. Similar studies were limited in their scope to changes of carbon storage in the soil organic carbon pool (Egoh et al. 2011) and the belowground biomass pool (Shangguan et al. 2014), throughout the past to present.

Our study overcame the aforementioned environmental assessment problems in developing countries by developing an integrated modeling approach. The InVEST carbon model, GEE coding, Cellular Automata Markov Chain (CA-MC) model, and the Intensity Analysis (IA) method were used to measure spatiotemporal impacts of LUCC on carbon storage and sequestration for historical (2000-2019) and future (2019 -2046) trends in a dryland ecosystem. The Jiroft plain, an arid agro-urban ecosystem, as one of the most suitable parts of the Iranian plateau for tropical crop cultivation, which has experienced severe LUCC (Agricultural Organization of Jiroft County 2013), was selected as the case study. The objectives of our integrated modeling were to:

1. Investigate the LUCC process in the Jiroft plain at the landscape scale through GEE coding, design a future scenario by applying the CA-MC model and the IA method;

2. Model carbon storage and sequestration and explore the mechanisms using InVEST;

3. Quantify provision and value in carbon storage and sequestration associated with LUCC;

4. Understand the spatial distribution and characteristics of carbon storage and sequestration over time based on the landscape scale to achieve comprehensive knowledge for decision-making processes of ecosystem management. 


\section{Material and methods}

\section{Study area}

The Jiroft plain is part of the Jazmourian Basin in Southern Kerman, Iran. The boundary was determined at the landscape scale, which was suitable to achieve a balance among multi-objectives, including production, conservation, and livelihood benefits over time and adapt to changing conditions (Cordingley et al. 2016; Luo et al. 2019; Sandker et al. 2010; Sayer et al. 2017). Different criteria, including elevation of the plain, Halil Roud River existence as the mainstream, human settlements, farmland, and other land use, were considered to define the boundary of the pilot landscape unit (Agricultural Organization of Jiroft County 2013). The plain is located in arid regions ranging from $28^{\circ} 12^{\prime} \mathrm{N}$ to $29^{\circ} 13^{\prime} \mathrm{N}$ and $57^{\circ} 15^{\prime} \mathrm{W}$ to $57^{\circ} 17^{\prime} \mathrm{W}$ (Fig. 1 ). The mean annual temperature and precipitation range from -4 to $+45{ }^{\circ} \mathrm{C}$ and 140 to $170 \mathrm{~mm}$, respectively. The altitude varies between 456 and $1318 \mathrm{~m}$ above sea level (masl), and the overall slope is from north to south (Jiroft Municipal Statistics Bureau 2017; Kerman Municipal Statistics Bureau
2015). This plain is one of the most suitable parts of the Iranian plateau for tropical crop cultivation, with an area of 36 $491 \mathrm{~km}^{2}$. It has a vital role in providing multiple ESs (e.g., agriculture), on which the local population depends on livelihood (Agricultural Organization of Jiroft County 2013).

\section{Methods}

In our study, an integrated model based on the impacts of two different LUCC scenarios on the spatial and temporal provision and value of carbon storage and sequestration was developed. The general workflow to achieve the integrated model is shown in Fig. 2. Our methodology consisted of four main stages: (1) determination of structural LUCC of the case study from 2000-2019 through the comparison and analysis of the basic land use/ land cover (LULC) using GEE coding and the IA method; (2) design of future LULC scenarios to 2046 applying CA-MC and (3) calculation of carbon stock from 2000-2019 and; (4) spatial change of the carbon sequestration value under the future scenarios using the InVEST model.
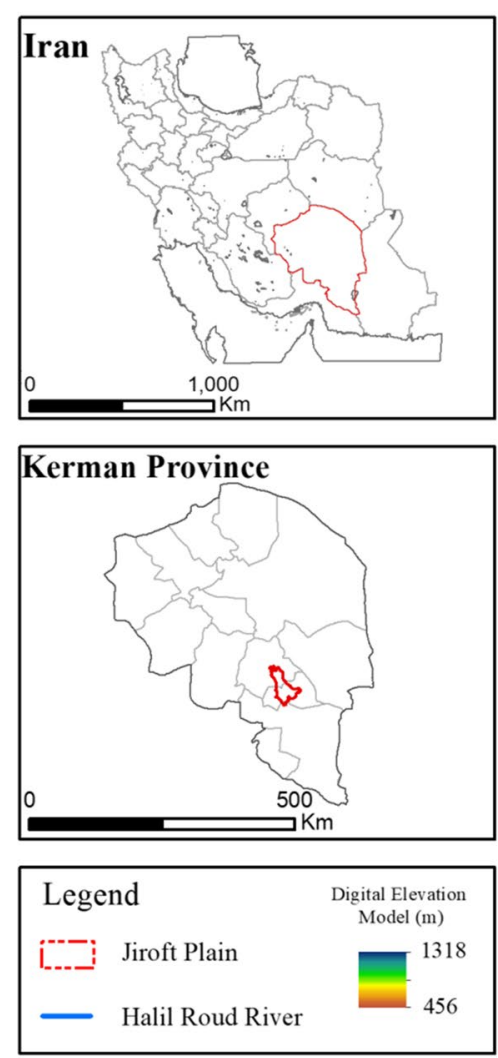

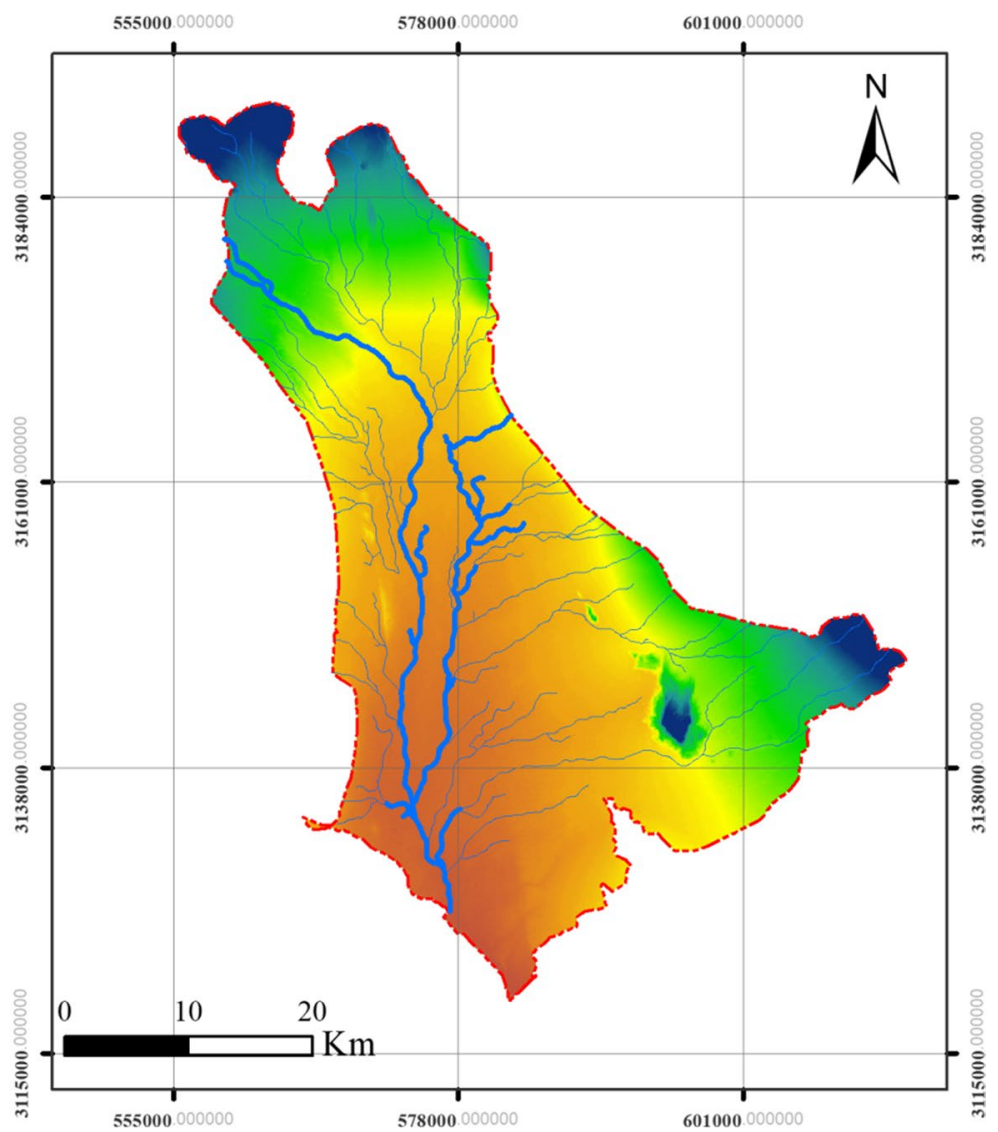

Fig. 1 Location of the study area-the Jiroft plain, Iran 


\section{Data description of LULC prepared by GEE}

We used GEE (Sidhu et al. 2018) to carry out simultaneous temporal and spatial LUCC analysis based on satellite imagery collection. The image classification in GEE was performed by using the support vector machine (SVM) algorithm. The SVM is a nonparametric classifier based on statistical learning theory that was initially proposed by Kavzoglu and Colkesen (2009). Landsat and Sentinel images were used to separate the agriculture from the forest, orchard, and the other land-use categories. In selecting the appropriate image from a collection of Landsat images, surface reflectance criteria including cloud-free or zero cloud cover and the summer season (July-September) were considered. Also, to include only relevant data that supports the purpose of the visualization, the filer on image collection was used (Google Earth Engine 2012).

\section{Accuracy assessment}

The accuracy of each classification in the GEE is defined as an error matrix called a confusion matrix (Congalton, 1991), representing the validation accuracy. Therefore, to assess accuracy in the SVM classifier, the confusion matrix was applied (Stehman, 1997). The accuracy is estimated from training data compared to each class's actual data that obtained from Google Earth (2015). In the accuracy assessment step, 75 points were derived from each classified image and uploaded to Google Earth Pro. Also, these images were the basis for calculating the overall accuracy and also evaluating the classification accuracies.

\section{Change detection of LULC through the Intensity Analysis (IA) method}

Detection of LUCC is an effective way to determine the human effects on the ESs (Yirsaw et al. 2017). The intensity analysis (IA) of LUCC as a top-down hierarchical accounting framework (Sang et al. 2019) focuses on the absolute amount of LUCC (Zhou et al. 2014) and the intensity of transformation (Teixeira et al. 2016). This method consists of three levels, including interval, category, and transition (Pontius et al. 2013). In this study, the IA method at the category level was considered for the detection of LUCC. The intensity change of each category within a specific time interval was evaluated at this level. The IA method uses uniform intensity (U), annual loss intensity (Lti), and annual gain intensity of $(\mathrm{Gtj})$ to explain LULC for a specific category. If Lit or Gtj is higher than $\mathrm{U}$, then that category is an active loser or gainer. Otherwise, the category is defined as a dormant loser or gainer (Sang et al. 2019).
Fig. 2 The general workflow of detecting spatial-temporal changes in carbon storage and sequestration

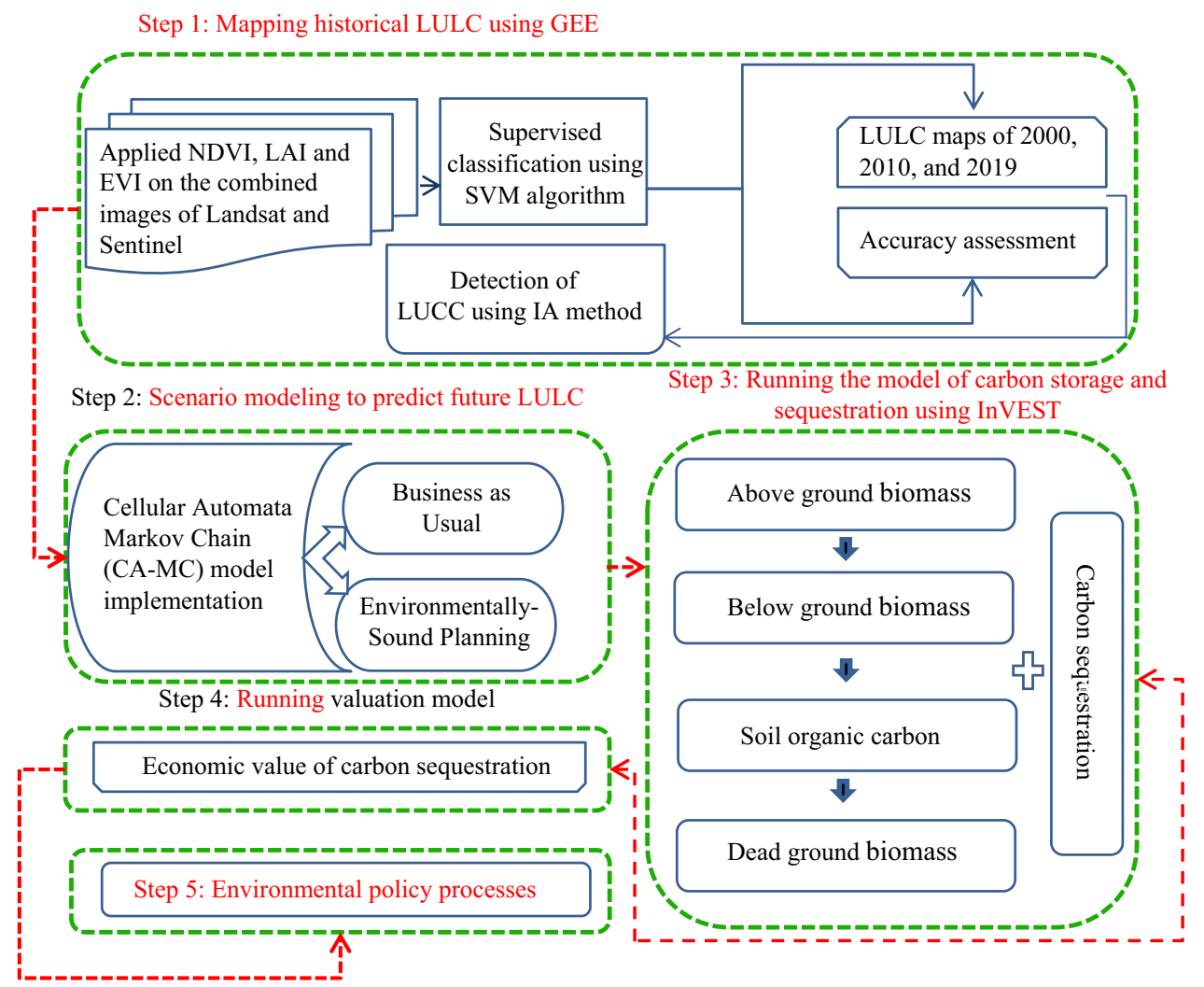




\section{Cellular Automata-Markov chain (CA-MC) model implementation}

The prediction of the future LULC dynamics is a complex process. This complexity involves various factors, such as economic and social conditions, ecological constraints, and different stakeholders' perspectives in managing future plans (Cassidy et al. 2010; Singh et al. 2015). Therefore, applying the proper prediction method that considers different future scenarios can help understand these complex processes. In this study, the CA-MC model in TerrSet software (version18.31) was used to simulate two different future LULC scenarios, which we termed environmentally sound planning (ESP) and the business as usual (BAU) scenarios. The CA-MC is recognized as the most promising method among many LULC scenario modeling tools, which analyses both spatial and temporal dynamics of complex systems (Regmi et al. 2017; Wu et al. 2019). The MC sub-model is a stochastic process that analyses the probability of a change from one state to another at the temporal dimension (Zhou et al. 2012). The CA sub-model conceptualizes the spatial dimension of LUCC (Hamad et al. 2018). This sub-model consists of a collection of cells organized in an arbitrary form of cells inside a grid-like structure (Ghosh et al. 2017). The temporal and spatial state of neighboring cells has an effect on each cell's state (Reddy et al. 2017). In this study, to define neighborhoods of each cell of the category, $5 \times 5$ pixels were applied as a standard contiguity filter (Hamad et al. 2018). The historical LULC layer from 2000 to 2010 was used for the calibration phase of the CA-MC model. Also, the image of 2019 was considered for validating the predictions of CA-MC. Finally, the Kappa index of agreement was used to evaluate the model's performance during the calibration of the BAU and ESP scenarios.

The first scenario, BAU, is a reference case scenario based on the historical trajectories (2000-2019), which considers social, economic, and population growth (Samie et al. 2017). This scenario assumes that the historical trend will continue until 2046 based on the conditional probability images without constraints based on the real conditions (Hamad et al. 2018). In this scenario, the resultant LULC change patterns for the future occur based on their historical trajectories. It is noteworthy that the historical trend of urbanization in the Jiroft is changing. The lack of sufficient facilities for thecurrent and next generation (Jiroft Municipal Statistics Bureau, 2017) and climate change impacts (the temperature in thisarea reaches about 60 degrees) have increased the migration rate from the Jiroft to the other cities(Kerman MunicipalStatistics Bureau, 2018). That this increasing migration rate is reflected in future forecasts.

The second scenario, ESP, depicts the future LULC by considering some limitations in controlling the development and preventing deforestation through management programs.
In this regard, conditional probability images were replaced with multi-criteria evaluation-derived (MCE-derived). Hence, it is possible to regulate the future trajectory of the change in LULC depending on various environmental influences, increasing migration rate, physical boundary conditions, economic and social conditions, ecological constraints, as well as stakeholders' perspectives and desires. These criteria effectiveness termed as Boolean operations or linear combinations can be evaluated regarding a specific objective (Malczewski 1999). As output, suitability map layers are generally constructed with respect to their objective (e.g., a LULC-category). The needed information for this scenario includes the rate of population growth and the minimum necessary land area to meet each individual demand in the Jazmourian basin, which was obtained from the Kerman Province Land Use Planning Report (Kerman Province Land Use Planning Report 2014).

\section{Modeling of carbon storage and sequestration through InVEST}

The carbon module uses a simplified carbon cycle to estimate the amount of static carbon storage and dynamic sequestration for each cell in a specific region (He et al. 2016; Tallis et al. 2013). This module considers four carbon pools, including aboveground carbon density, belowground carbon density, soil organic carbon, and dead organic matter (Tallis et al. 2013). The calculation of the carbon storage $C$ $m, i, j$ in a given grid cell $(i, j)$ with land use type " $m$ " can be achieved by Eq. 1 (Aalde et al. 2006):

$C_{m, i, j}=A \times\left(C a_{m, i, j}+C b_{m, i, j}+C s_{m, i, j}+C d_{m, i, j}\right)$

In this formula, $\mathrm{A}$ is the real area of each grid cell (ha). Also, $\mathrm{Ca}_{\mathrm{m}, \mathrm{i}, \mathrm{j}}, \mathrm{Cb}_{\mathrm{m}, \mathrm{i}, \mathrm{j}}, \mathrm{Cs}_{\mathrm{m}, \mathrm{i}, \mathrm{j}}$, and $\mathrm{Cd}_{\mathrm{m}, \mathrm{i}, \mathrm{j}}$ are the aboveground carbon density, belowground carbon density, soil organic carbon density, and dead organic matter carbon density (i, j), respectively. Finally, carbon storage " $C$ " and carbon sequestration " $\mathrm{S}$ " can be calculated by Eqs. 2 and 3 for the whole case study region (Aalde et al. 2006):

$C=\sum_{m=1}^{n} C_{m, i, j}$

$S=C^{T 2}-C^{T 1}$

In Eq. 3, $\mathrm{C}^{\mathrm{T} 2}$ and $\mathrm{C}^{\mathrm{T} 1}$ demonstrate static carbon storage in years $\mathrm{T} 2$ and $\mathrm{T} 1(\mathrm{~T} 2>\mathrm{T} 1)$. The needed data for running the carbon storage model were the LULC map and the biophysical table containing columns of LULC, ' $\mathrm{C}_{-}$above,' 'C_below,' 'C_soil,' and 'C_dead.' The required biophysical data are presented in Table 1, which was obtained from sampling and field experiments by Liang et al. (2017) and the InVEST user's guide (Sharp et al. 2020). The data regarding 
the carbon sequestration model were a current and future LULC scenarios map for calculating the net change of carbon storage pixel by pixel over time.

The last part of carbon modeling is estimating the economic value distribution of carbon sequestration/loss (not storage) under each scenario over time. This function, Eq. 4, requires three inputs, including I) "V," the monetary value of each unit of carbon, II) "r," a monetary discount rate, and III) "c," the change in the value of carbon sequestration over time (Tallis et al. 2013):

$$
\begin{aligned}
\text { value }-\mathrm{seq}_{x}= & V \frac{\text { sequest }_{x}}{\mathrm{yr} \_f u t^{-} \mathrm{yr}_{\text {cur }}} \sum_{t=0}^{\mathrm{yr}=\mathrm{fut}^{-} y r-\mathrm{cur}^{-1}} \\
& \frac{1}{\left(1+\frac{r}{100}\right)^{t}\left(1+\frac{c}{100}\right)^{t}}
\end{aligned}
$$

Unfortunately, the long-term data related to the social cost of land-use change, especially the destruction of orchards and forests in Iran, could not be found. Therefore, the data from international studies of economic value related to the study area's conditions were considered (IPCC 2006).

The first input " $\mathrm{V}$ " is estimated based on the social cost of carbon (SCC) that is released $\mathrm{Mg}$ of carbon in the atmosphere in case of excess of the threshold. Some studies (Haight et al. 2020; Melaku Canu et al. 2015) estimated the total values of carbon sequestration as SCC based on the damages caused by releasing an additional ton of carbon in the atmosphere. There are some sufficient criteria to determine this value, including differences in landscape, applied discount rate, and carbon cost and benefit of carbon sequestration. Estimated values for each ton of carbon range widely from \$32 US dollars (Nordhaus 2007) to \$326 US dollars (Stern 2007). To estimate the cost of loss per ton of carbon or the benefit from storing per ton of carbon, an alternative method is to regard the equivalent cost of carbon sequestration per ton. This method considers the cost of storing carbon by public facilities such as power plants (Socolow 2005; Socolow and Pacala 2006; Tol 2017). The mentioned studies estimated this price equal to be approximately $\$ 110$

Table 1 Carbon pools of different land-use types in the InVEST model (unit: $\mathrm{Mg} \mathrm{C} \mathrm{ha}^{-1}$ ). Ca refers to the aboveground biomass; $\mathrm{Cb}$ to the belowground biomass; Cs to the soil organic carbon; and $\mathrm{Cd}$ to the dead organic matter, respectively

\begin{tabular}{lllll}
\hline Land-use type & $\mathrm{Ca}$ & $\mathrm{Cb}$ & $\mathrm{Cs}$ & $\mathrm{Cd}$ \\
\hline Agriculture & 3 & 2 & 853.13 & 1.5 \\
Forest & 45.09 & 9.03 & 13.1 & 5.6 \\
Unused land & 0.1 & 1.9 & 0.8 & 0 \\
Urban & 0.4 & 0 & 1.73 & 0 \\
Water & 0 & 0 & 0 & 0 \\
\hline
\end{tabular}

US dollars. In our study, the same cost per ton of carbon was considered.

The second input, "r," is the discount rate that expresses the preference of the community over immediate benefits and future benefits. Based on the cost-benefit evaluation of an environmental assessment by the US government, this input is set to $7 \%$ in the carbon module of InVEST. This rate varies for different landscape conditions and local requirements. According to the Iranian studies economic valuation, the discount rate of $12 \%$ was considered in our research (Iranian statistical Yearbook 2017).

The third data, "c," reports the change of carbon price in the form of the annual rate. These data demonstrate the sequestered carbon value resulting from emissions impact on damages associated with expected climate change. The default value is set to zero. A number greater than zero means that the social value of carbon sequestration in the future is less than its value of the present time. In our study, due to attention the high probability of exacerbation of the impacts induced by climate change, the default value of zero was considered.

\section{Results and discussion}

\section{Results}

\section{Detection of LUCC by IA method}

Figure 3 and Table. 2 show the land use and land occupation patch classifications under different scenarios, including historical trend, and the BAU and ESP scenarios using GEE. The overall accuracy of classification of 2000, 2010, and 2019 was $86.8,84.6$, and $87.5 \%$, respectively. The major types of LULC in the Jiroft plain were unused-land, forest, urban, agriculture, and water. From 2000 to 2019, the urban category as the most dynamic land feature that followed by agricultural land demonstrated stable increasing trends according to the historical directions of growth. We projected that the increasing trend in urban land cover would continue in both the BAU and ESP scenarios from 2019 to 2036. Conversely, the future growth of agriculture was limited under the ESP scenario. However, the unused-land showed the largest decrease, followed by forest and water. The unused-land decreased sharply from 2000 to2019, and this reduction continued under the ESP scenario and then increased under the BAU scenario in 2046. The trend of forest decreased dramatically under historical and the BAU scenario and increased under the ESP scenario. Finally, the least dynamic category with the minimum areal extend in the Jiroft plain was water. The areal extent of the water decreased from in 2000 under the different scenarios. 
The IA method was applied at the category level for three cross-tabulation attempts, including I) historical trend (2000-2019), II) BAU scenario (2019-2046); and III) ESP scenario (2019-2046). Compared to the historical profile (Fig. 4), the value of uniform change intensity was considerably lower for the BAU (1.3\%) and ESP (1.9\%) scenarios.

Specifically, during the historical period (2000-2019), the unused-land, forest, and water were active losers and dormant gainers. In terms of the water body, because the water body in 2000 is of very low areal extent, it gradually decreased from 0.7 to $0.2 \%$ of the study area in 2019 due to agricultural activities. It means that although the water body represents a very low percentage of the study area in 2000, the intensity of its growth is significant relative to other land categories. In contrast, the urban and agricultural land covers were active gainers and dormant losers and depicted higher levels of gaining intensities as active gainers.

It is noteworthy that there were also important differences between the two predictive planning alternatives at the category level. According to the BAU scenario (Fig. 4b), the urban and agricultural lands are dormant losers and active gainers. In contrast, the forest category is a dormant gainer and active loser. Also, in this scenario, the unused land class is dormant for both losing and gaining intensities. The water (a) Baseline landscape (2000)

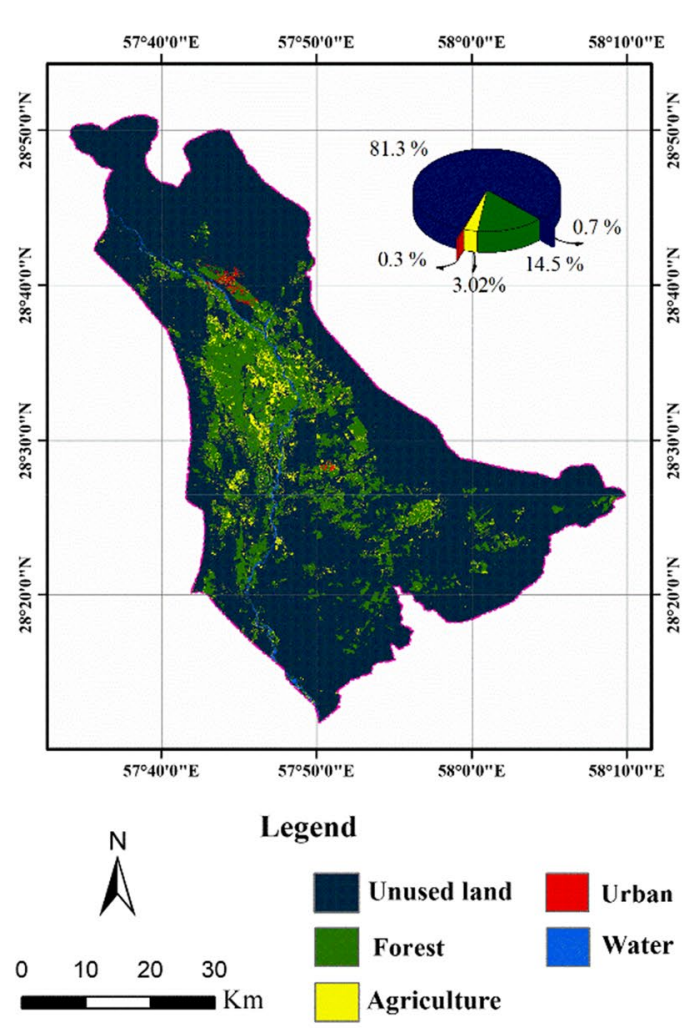

(b) 2010

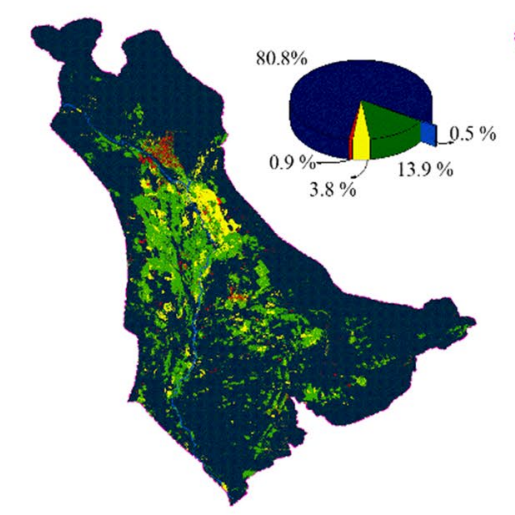

(d) Business as usual (2046)

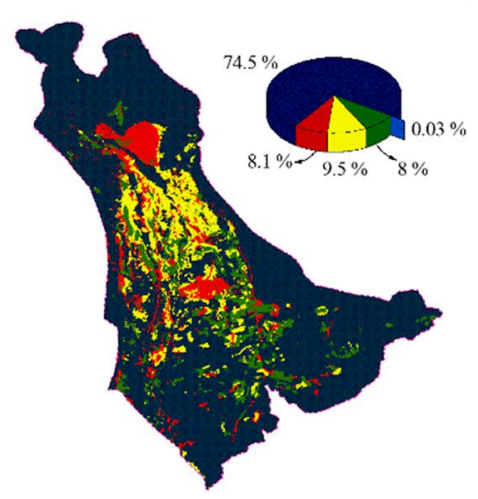

(c) Current landscape (2019)

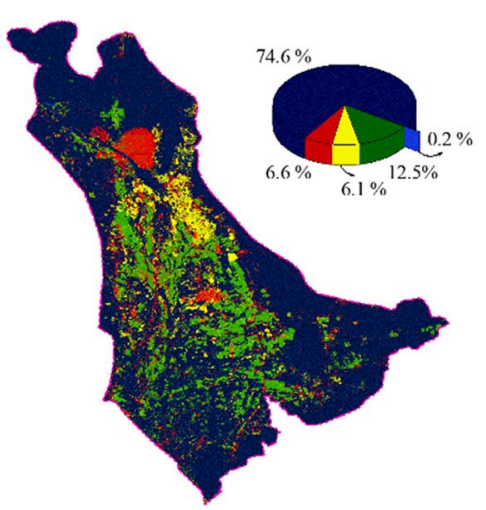

(e) Environmentally-sound planning

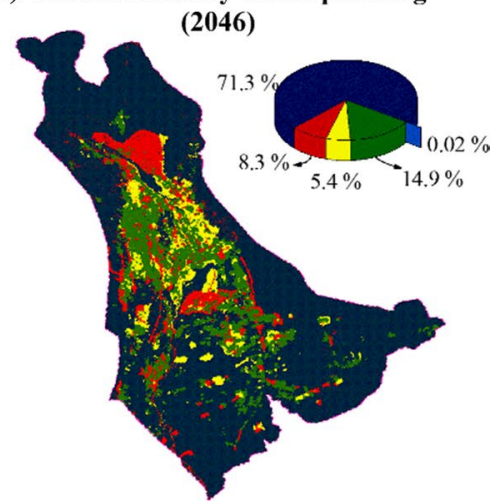

Fig. 3 LULC layers a 2000, b 2010, c 2019, d 2046 under business as usual scenario and, e 2046 under environmentally sound planning scenario

Table 2 A comparison of the quantity of LULC changes from the baseline to the current situation and future scenarios

\begin{tabular}{|c|c|c|c|c|c|}
\hline \multirow[t]{2}{*}{ Land use class } & \multicolumn{5}{|c|}{ Area (Percent /Km2) } \\
\hline & 2000 & 2010 & 2019 & 2036-BAU & 2036-ESP \\
\hline Unused-land & $81.3 \%(1297.01)$ & $80.8 \%(1288.80)$ & $74.73 \%(1191.94)$ & $75.03 \%(1196.72)$ & $71.3 \%(1137.7)$ \\
\hline Forest & $14.55 \%(232.20)$ & $13.82 \%(220.57)$ & $12.5 \%,(198.99)$ & $7.5 \%(119.62)$ & $14.85 \%(236.85)$ \\
\hline Urban & $0.33 \%(5.38)$ & $0.95 \%(15.27)$ & $6.6 \%,(105.55)$ & $8.10 \%(129.19)$ & $8.33 \%(132.86)$ \\
\hline Agriculture & $3.01 \%(48.10)$ & $3.87 \%(61.80)$ & $6.1 \%(97.42)$ & $9.37 \%(149.45)$ & $5.45 \%(86.92)$ \\
\hline Water & $0.77 \%(12.29)$ & $0.53 \%(8.54)$ & $0.1 \%(1.01)$ & $0.02 \%(0.31)$ & $0.01 \%(0.15)$ \\
\hline
\end{tabular}


category shows a dormant loser. Under the ESP scenario (Fig. 4c), the urban category is the only active gainer among the different patterns of change. At the same time, the agriculture and unused-land became active in losing their intensities. The urban class was an active gainer and a dormant loser during the historical trends and predictive scenarios, representing continuous growth from 2000 to 2046.

\section{Measuring quantitative changes of carbon at the landscape}

The InVEST carbon model's first outputs were the landscape's carbon storage maps under different scenarios, including historical growth trajectories, BAU, and ESP scenarios (Figs. 5a-e). Based on the historical growth trajectories, the urban and agriculture categories showed constant increasing trends from the north to the south of the region. Simultaneously, forests with a decreasing trend were distributed in the center of the plain. According to the modeled distribution, the carbon storage volumes increased within the center and reached a minimum in the northern and southern urban areas. The minimum amount of carbon was $0.8 \mathrm{Mg}$ stored in the urban areas, and the maximum amount was 19.4 Mg in forests. Also, the average carbon storage was 9.7 ton/ha for the current landscape (2019). This value will change to 7.2 ton/ha and 11.3 ton/ha under the BAU and ESP scenarios in 2046, respectively.

A comparison of carbon storage and sequestration changes under different scenarios is shown in Fig. 6. The results of stored carbon showed a decrease from 4.6 million $\mathrm{Mg}$ in 2000 to 3.1 million $\mathrm{Mg}$ in 2019. The BAU scenario results showed rapid land-use change caused by human activities from 2019 to 2046 . The BAU scenario with rapid changes in land use caused by human activities in 2019-2046 was expected to decrease sequestered carbon by $2,624,113 \mathrm{Mg}$, with an average decrease in sequestration of $-475,547 \mathrm{Mg}$. The carbon storage loss will occur mainly in the forest (Nonini and Fiala 2019). The ESP scenario resulted in moderate protection of LUCC and led to a smaller disturbance by human activities. In this scenario, the carbon storage will decrease to 3,705,491 Mg from 2019 to 2046 , with an average sequestration of $+605,830 \mathrm{Mg}$. The obtained results from the carbon storage model showed that the ESP scenario, with a medium protective socioeconomic development, saved a large amount of stored carbon in comparison with the historical period and BAU scenario.

The second output of the carbon model (Fig. 7a, b) was carbon sequestration maps under BAU and ESP scenarios. Raster maps showed the difference in carbon stored between the current and future landscape. The values of this map included negative and positive ranges. The negative values indicate lost carbon, and positive values indicate sequestered carbon in Mg per pixel. Areas with the highest negative or positive values showed the most considerable LULC change. The result of the BAU scenario showed -15.0 ton/ha as the maximum loss of carbon in the degraded forests. Also, 3.7 ton/ha was measured as the maximum carbon sequestration capacity. Alternatively, in the destroyed landscape parts of the plain under the ESP scenario, the maximum carbon loss (2000-2019) will be - 11.2 ton/ha. The maximum sequestration in areas where the forest category will be restored is expected to reach +15.0 ton/ha (Fig. $7 b$ ).

\section{Carbon sequestration valuation}

The carbon model's final output was the economic value distribution of carbon sequestration under different predictive scenarios, as shown in (Fig. 6c, d). Based on the
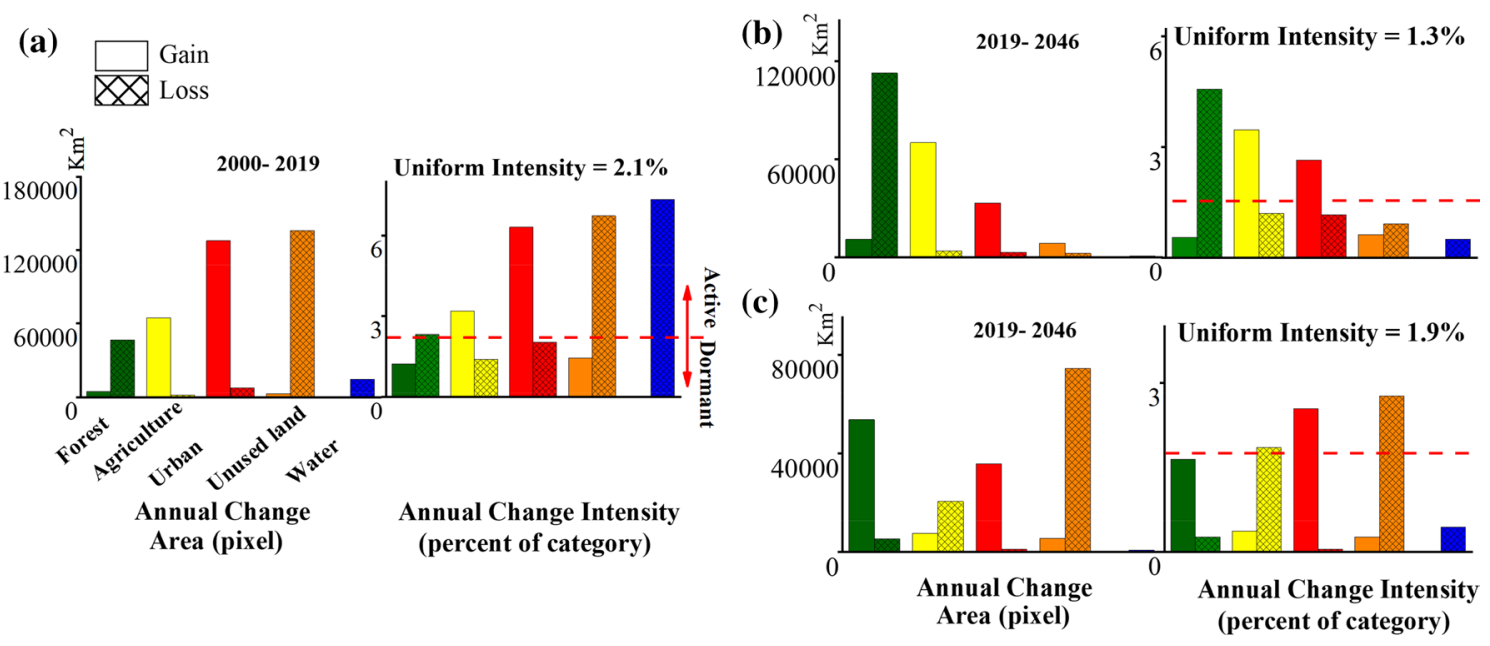

Fig. 4 Intensity change of category level in three time intervals: a historical time profile (2000-2019), b BAU scenario (2019-2046), and c ESP scenario (2019-2046) 
(b) Carbon Storage in 2010

(a) Carbon Storage in the baseline landscape (2000)
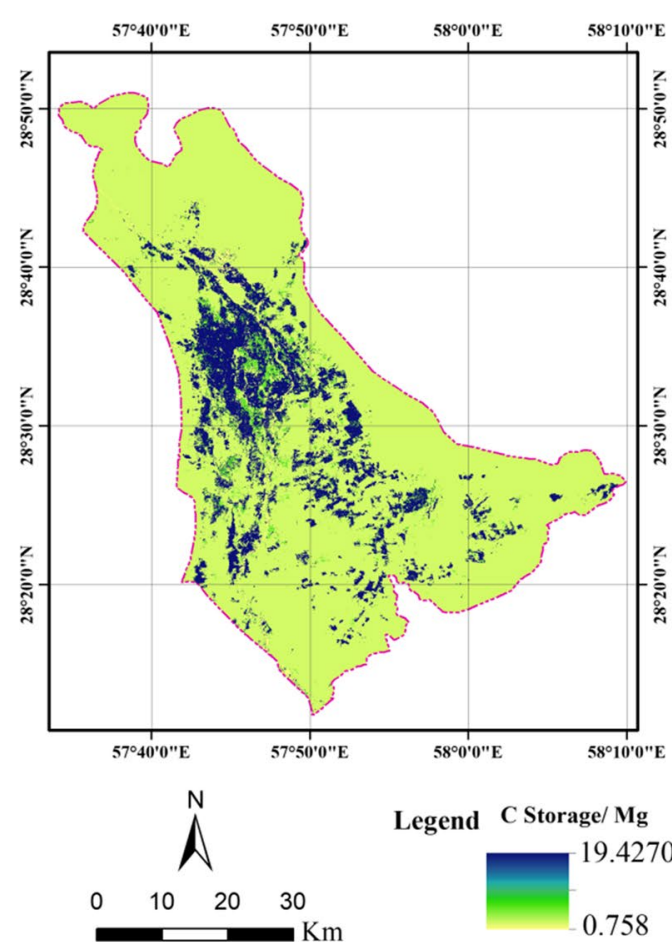

Legend C Storage/ $\mathrm{Mg}$

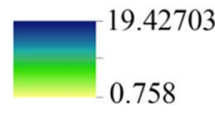

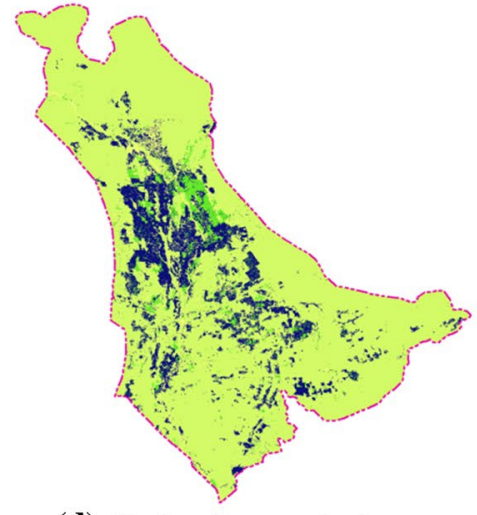

(d) Carbon Storage during 2019- 2046 (Under BAU scenario)

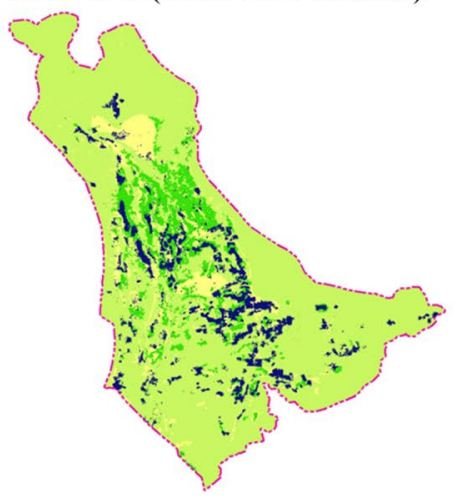

(c) Carbon Storage in current landscape (2019)

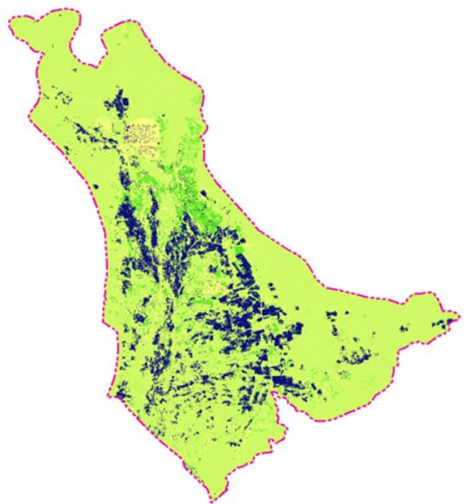

(e) Carbon Storage during 2019- 2046 (Under ESP scenario)

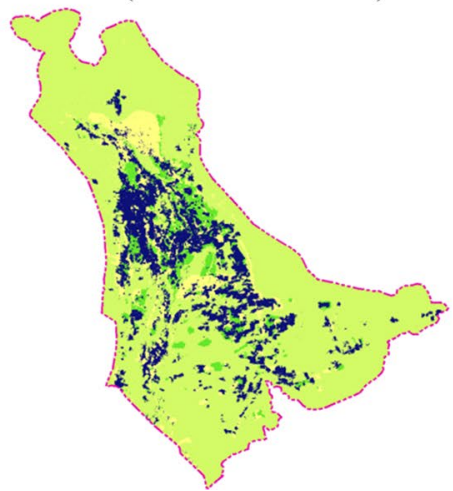

Fig. 5 Comparison of quantities of carbon storage from the baseline to the current situation and under the future scenarios of BAU and ESP

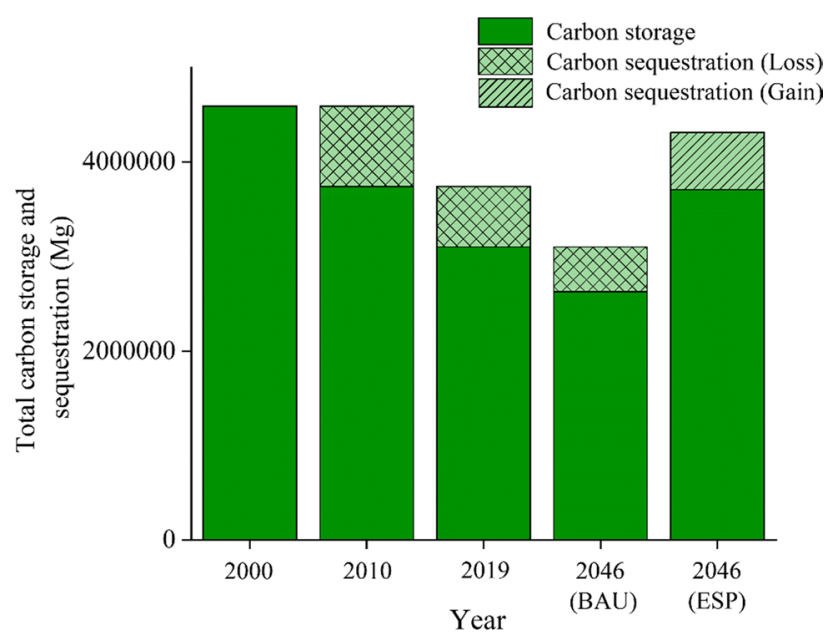

Fig. 6 Comparison of carbon storage and sequestration changes under different scenarios

BAU scenario, a reduction of carbon sequestration of about $-475,547$ tons will occur between 2019 and 2046 . Considering US\$ 110 as the cost per ton of carbon emission and $12 \%$ as the discount rate with this potential drop, the cost of damage in the next two decades will be about US\$ 36 million. Additionally, in the case of implementation of the ESP scenario, the total potential of sequestration will increase to $+605,830$ tons. Using the same cost per ton and discount rate, the net present value between 2019 and 2046 will be about US\$ 45 million. In the case of deforestation under the BAU scenario or forest rehabilitation under the ESP scenario, the carbon loss's minimum cost showed -470.4 and -342.1 per ha, respectively. Also, the maximum carbon sequestration was estimated to be +27.7 per ha for the BAU scenario and +470.7 for the ESP scenario, respectively.

\section{Discussion}

\section{Driving factors of LUCC and carbon dynamics}

The integration of land use scenarios and the InVEST model can reduce the complexity of the issue of assessing the spatial and temporal impact of LUCC on carbon storage and sequestration at the landscape scale, particularly in dryland ecosystems in developing countries that face high LUCC 
Fig. 7 a-b Comparison of quantities of carbon sequestration under the future scenarios of BAU and ESP; $\mathbf{c}-\mathbf{d}$ economic value of carbon sequestration under the future scenarios of BAU and ESP (a) Carbon sequestration during 2019- 2046 (Under BAU secanrio)

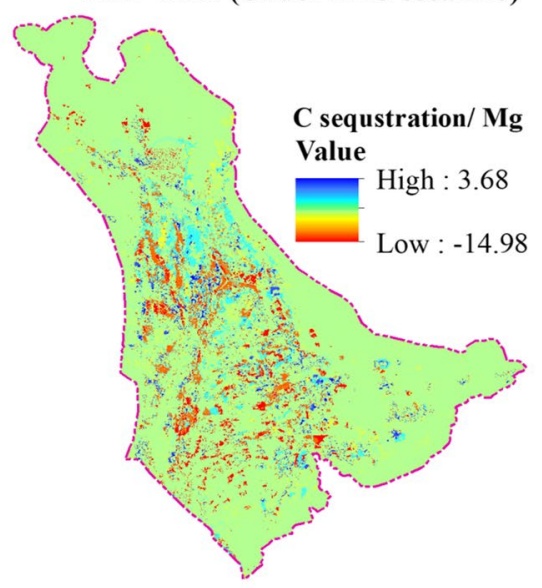

(b) Carbon sequestration during 2019- 2046 (Under ESP secanrio)

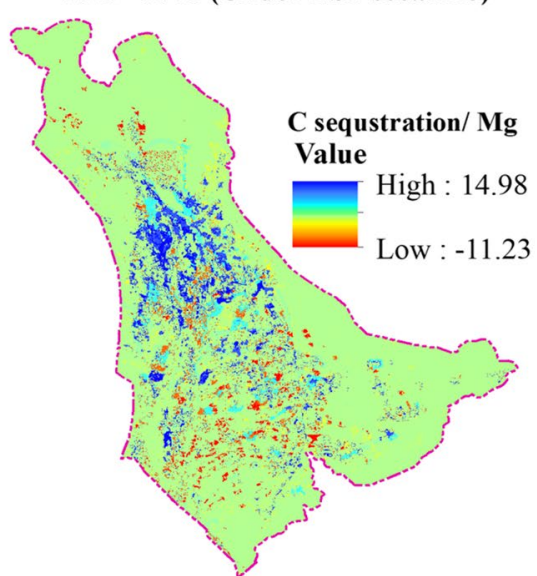

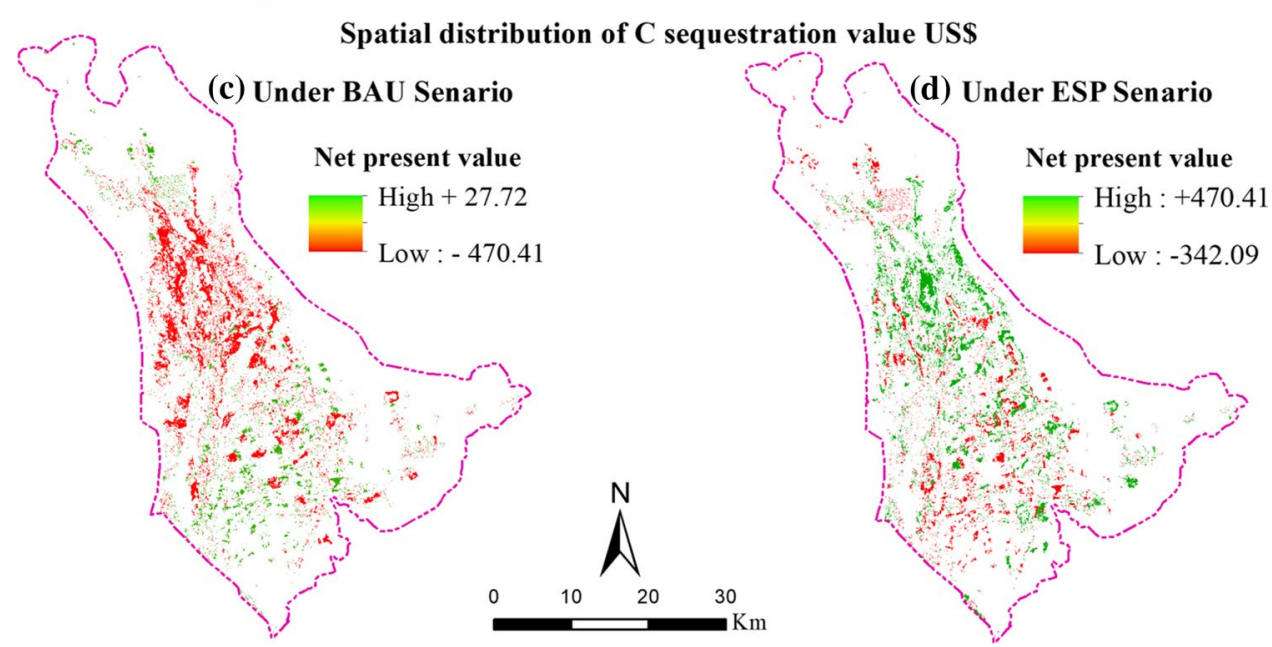

intensity. We detected LUCC patterns over time by comparing the 2000, 2010, and 2019 LULC. We found that major LUCC trends (2000-2019) included the rapid expansion of agriculture and urban land cover; and sharp decreases in the forest and unused-land. Our findings regarding the LUCC pattern are similar to the results of other parts of the Jazmourian basin (Mazaheri et al. 2013; Sanjari 2015). The main driving factors associated with the LUCC mentioned above in the Jiroft plain include several contributing factors, such as rapid population growth (Kanianska 2016) or the high rate of the population transfers from the rural areas to the cities (Jiroft Municipal Statistics Bureau 2017). Deforestation has led to an increase in agricultural and urban land use to meet the demand for rising food requirements and other fundamental needs of the society in the basin (Rahbarian and Sardoei 2014). It is noteworthy that the biophysical characteristics of the basin (e.g., proper slope, elevation, fertile soil) have allowed for the cultivation of tropical crops. Another critical driving factor is the poor implementation of agricultural development plans based on the background policies, which has led to moving the plain into a forbidden status in terms of agricultural activities in 2009 (Sanjari 2015).

If the historical trend (2000-2019) continues without any constraints (i.e., BAU scenario) over the next two decades, drastic degradation of natural covers such as forests will occur. Also, we anticipate a considerable reduction in carbon sequestration from converting the forests and unused-land to urban settlements and farmland. Various studies have shown that the growth of agricultural activities and human settlements leads to the degradation of natural land use over time (Chuai et al. 2013; Fu. 2017; Sang et al. 2019). Grinand et al. (2017) estimated the average net loss of carbon storage for southeast Madagascar, where forest cover went from 10.7 and $5.2 \%$ for the 30 and $100 \mathrm{~cm}$ layers, respectively. In other areas, Mahowald et al., (2017) found conversion from forest to cropland via deforestation led to carbon loss of $490 \mathrm{Pg} \mathrm{C}$ between 1850 and 2300, compared to a carbon loss of 230 $\mathrm{Pg} \mathrm{C}$ over the same time interval caused by climate change alone (230 Pg C).

If the land use policies for the conservation of the forests under the ESP scenario are adapted, the costly process of 
the historical trend can potentially be halted or reversed. Ontl et al. (2020) has noted that the active restoration of the degraded tropical rainforests of the Western Ghats, India, could promote recovery of its carbon storage within 7-15 years of rehabilitation.

\section{Explanation of carbon at fine spatial and temporal scales}

According to Fang et al. (2007) and Zhang et al. (2015), forests have the highest amount of carbon density at about 19.4 Mg. The minimum amount of carbon was $0.8 \mathrm{Mg}$ stored in urban land cover, which is in agreement with the literature (Chuai et al. 2013; Zhang et al. 2015). The amount of carbon storage decreased from 4.6 million $\mathrm{Mg}$ in 2000 to 3.1 million $\mathrm{Mg}$ in 2019, with average sequestration of -1.5 million $\mathrm{Mg}$. This decreased amount of carbon storage was due to LULC converting from forest to agriculture and urban land cover. In terms of carbon loss storage and sequestration potential, Lü et al. (2014) showed that the expansion of agriculture and urban land cover led to a significant reduction in the social cost of carbon (SOC) over time. Also, the study by Wang et al. (2016) showed that the transition from agriculture to urban areas had considerable impacts on the SOC.

In the BAU scenario, as a result of human activities, we estimated a reduction of about 2.6 million $\mathrm{Mg}$ in carbon storage with average sequestration loss of $-475,547 \mathrm{Mg}$ from 2019 to 2046. Lü et al. (2014) showed that the expansion of agricultural and urban land led to a significant reduction of SOC. Also, in terms of carbon stock loss and the possibility of atmospheric release, there could be costs up to US\$ 36 million at the landscape scale. This result is similar to findings from Liang et al. (2017) regarding carbon loss storage and sequestration potential due to the conversion of forest to agriculture and the urban land cover.

Based on the results of carbon modeling under the ESP scenario, carbon storage will increase to 3.7 million $\mathrm{Mg}$ from 2019 to 2046, with average sequestration of $+605,830$. According to this increase, a net present value of about US\$ $44,543,304$ will be generated over the next two decades (2019-2046). The reason for this increase was the preservation of forests and restoration of agricultural land cover to forests, which will lead to the prevention of carbon emissions. Cheng et al. (2013) demonstrated that transitioning from agriculture to forest led to a considerable increase in the SOC. Liang et al. (2017) showed that the most carbon storage could be saved with restrictive policies that strictly protect the forests. Also, results by Lü et al. (2014) support our findings that the transition from grassland to semishrubby would bring significant carbon sequestration benefits. Boix et al. (2009) and Poeplau and Don (2013) both demonstrated that the SOC would increase significantly by converting the agricultural land to forests.
The results of the carbon modeling showed that the average amount of carbon stored was different in the different regions. The estimated annual average amount of carbon in our study was 9.71 ton/ha in 2000, while Sil et al. (2017) estimated a value equivalent to 47.21 ton/ha, and MuñozRojas et al. (2011) reported a value of 15.84 ton/ha. Differences in these values are likely due to the differences in land cover types for each area, climatic conditions, and geographical context (Li et al. 2020; Polasky et al. 2011). Our study also estimated the carbon sequestration rate to be -0.95 ton/ha under the BAU scenario and 1.01 ton/ha under the ESP scenario. Sil et al. (2017) estimated the carbon sequestration rate to be about 1.4 ton/ha in the mountain region, while Ribeiro et al. (2011) estimated it to be about 1.1 ton/ha in the coastal zone. The main contributing reason for this difference between carbon sequestration rates may be due to the intensified trend of LUCC within different areas (Brovkin et al. 2013). For instance, our results showed a severe decrease in forest and orchard protection that would likely extend under the BAU scenario. In contrast, the LUCC trend in Sil et al. (2017) showed a continuous increase in forest cover under the forest scenario. Our study's calculated sequestration rate under the ESP scenario was similar to those estimated by Sil et al. (2017).

\section{Economic valuation}

Our economic valuation of carbon sequestration resulted in a minimum of US\$ $-470.41 \mathrm{ha}^{-1} \mathrm{yr}^{-1}$ and a maximum of US\$ $27.72 \mathrm{ha}^{-1} \mathrm{yr}^{-1}$ under the BAU scenario, and a minimum of US\$ $-342.09 \mathrm{ha}^{-1} \mathrm{yr}^{-1}$ to a maximum of US\$ $470.41 \mathrm{ha}^{-1} \mathrm{yr}^{-1}$ under the ESP scenario. Our results are in line with Sil et al. (2017), who found that the value of carbon sequestration with a different carbon price ranged from a minimum of US\$13.5 ha $\mathrm{yr}^{-1}$ when converting forest to grassland. The maximum was US $\$ 217 \mathrm{ha}^{-1} \mathrm{yr}^{-1}$ when grassland was converted back to forest. Padilla et al. (2010) showed that in the case of intense human activities (conversion of forest to human settlement and farmland), the spatial distribution of carbon sequestration value varied from a minimum of US\$ $-1361.23 \mathrm{ha}^{-1} \mathrm{yr}^{-1}$ to a maximum of US\$ $+230.43 \mathrm{ha}^{-1} \mathrm{yr}^{-1}$. In the landscape conservation scenario, this value ranged from a minimum of US\$ $-1349.24 \mathrm{ha}^{-1} \mathrm{yr}^{-1}$ to a maximum of US\$1361.23 $\mathrm{ha}^{-1} \mathrm{yr}^{-1}$. The different carbon price (US\$ 67 per Mg carbon) used in their study was higher than the value used in our study. The differences between our results reflect the uncertainty of the economic valuation of carbon storage (Sil et al. 2017) and the preferences of future societies on climate mitigation (Fleurbaey et al. 2019), which are mainly derived from different prices of carbon and emission trajectories. 


\section{Limitation and policy lesson}

We recognized some limitations in our study. Firstly, we recognize the difficulties of directly sampling the carbon pools for precise measurements of carbon storage. Therefore, there remains a considerable level of uncertainty in the calculated values of carbon storage and sequestration, which could be an area of future research. Secondly, we carried out LULC classification considering five broad classes that lacked a detailed carbon storage and sequestration assessment. Future work may include a finer resolution of LULC categories to increase the accuracy of carbon storage values. However, the current land use categories were resolved high enough to meet our study objectives.

Nevertheless, our study highlights the integration of ESs in the context of spatial planning and land use management through the preparation of spatial ESs maps at the regional scale. The outputs of this integrated assessment demonstrate that there is potential monetary value associated with the carbon storage and sequestration. We have shown that ESs maps can be used to identify hot spots with high supply of multiple ESs. These results provide a useful guide to quantify changes in carbon storage and sequestration that are driven by LUCC (Figs. 5, 6).

Additionally, we estimated the potential opportunity cost to farmers as a consequence of implementing the ESP scenario, as opposed to the BAU scenario. The difference in agricultural land use between BAU and ESP scenarios is $4.1 \%$. Potential agricultural land forfeited between BAU and ESP scenario $=$ catchment area $\times 4.1 \%=36,491 \mathrm{~km}^{2} \times$ $4.1 \%=1,496 \mathrm{~km}^{2}$. Conversion from $\mathrm{km}^{2}$ to acre: 1,496 $\mathrm{km}^{2} \times 247 \mathrm{acre} / \mathrm{km}^{2}=369,701$ acres. The 2016 gross value of wheat production was US\$206.35 per planted acre (Schaffer et al., 2018). Therefore, the maximum economic loss per year between BAU and ESP from not planting wheat is: 369,701 acres $x$ US\$ 206.35/acre $=$ US\$ 76.4 Million/ year. Projecting the BAU and ESP scenarios out over the next 25 years until 2046 and assuming that the agricultural land is fully utilized for all 25 years (i.e., agricultural expansion is not gradual), the potential gross value of loss wheat protection between BAU and ESP scenario is: US\$ 76.4 Million/year $\times 25$ years $=$ US\$ 1.91 billion. US \$1.91 billion represents the potential loss in agricultural production between the BAU and ESP scenarios over the next 25 years. In comparison, the value of carbon sequestration over the next 25 years in the ESP scenario has been estimated to be worth US\$ 44.5 million.

In fact, the environmental cost of LUCC for the shortterm economic benefit of the farmer has been associated with a reduction in the value and provision of carbon storage and sequestration ecosystem services over time. It is worth noting that the Jiroft plain is an arid ecosystem that depends mainly on groundwater for irrigation. Severe groundwater depletion has been observed in the region since 2000 (Adelisardou et al. 2021), where groundwater levels have declined by up to $17 \mathrm{~m}$ (Agricultural Organization of Jiroft County 2017). Although it may appear that you can have all the agricultural land plus increase the forests, the current rate of agricultural expansion is unsustainable in the Jiroft plain's arid climate. As explained previously, the rate of groundwater extraction for irrigation is currently causing rapid depletion of groundwater storage. Furthermore, projections of climate change suggest that periods of low rainfall and drought will occur with greater frequency in the Jiroft plain, thus exacerbating the already dry conditions. Finding a sustainable trade-off between forests and agricultural land, given the variety of stakeholders, is a matter of optimizing land use in a dynamic and complex socio-ecological system.

Indeed, continued deforestation poses a serious threat to the residents' long-term well-being in the Jiroft plain. The BAU scenario is limited to only short-term economic benefits for the local farmers and regional stakeholders through continued agricultural expansion. It is important to note that the BAU scenario is fundamentally unsustainable because over-expansion of agricultural land use has the potential to lead to local groundwater depletion and soil erosion issues that can eventually render the land agriculturally unproductive. Furthermore, our results show that the BAU scenario will dramatically reduce the overall carbon sequestration services within the Jiroft plain, which may lead to intensified climate change (e.g., droughts) over the long-term.

As forest cover continues to decline, ESs management through effective land management policies should be carried out (Bren d'Amour et al. 2017). The ESP scenario can be used as a guide to conserve the arid ecosystem at the landscape scale by applying local plans and training programs for the local communities. The development of payment schemes for ESs could be a way of protecting arid regions that tend to be overlooked locally. Implementing the land use scenario that emphasizes a reduction of carbon dioxide emissions (REDD + scenario) could offer a way forward (UN-REDD Programme 2008). This scenario estimates the rate of excess carbon sequestration and then discusses the issue of paying for ESs. REDD + is a policy that financially rewards efforts to reduce deforestation and carbon emissions in developing countries. In this case, preventing deforestation and preserving excess carbon means reducing the economic damage associated with climate change.

From science to policy, this ensemble of results could be used to provide an essential basis for decision-making regarding planning and management in similar arid landscapes. Therefore, the planning frameworks at the regional and national scales should use LULC types that not only preserve existing carbon stock level but also to promote higher 
sequestration with different land cover. Future management policy should focus on continuous monitoring actions for both the LULC pattern and carbon pools dynamic to reduce the uncertainty of the predicted model and increase the capability of an ES-based approach to provide superior support in the policy process.

\section{Conclusion}

Our main object was to consider the spatiotemporal impacts of land use/cover change intensities on carbon storage and sequestration, as well as the associated cost of those changes. Such estimates in developing countries, such as Iran, have typically been associated with poor quality data concerns, weak technical knowledge to implement appropriate assessment methods, and centralization on a single timepoint. We overcame these limitations by integrating Google Earth Engine, Intensity Analysis, Cellular Automata Markov Chain, and the InVEST model, which we applied to the Jiroft plain in southeastern Iran. Dynamic analysis of carbon storage and sequestration provision and value at the landscape scale under different scenarios was performed. Our results indicated that land use/cover change can strongly influence the spatial pattern of carbon storage and sequestration in the Jiroft plain over time.

Furthermore, there was a substantial monetary value associated with carbon storage and sequestration in the Jiroft plain. The future landscape under different scenarios is likely to affect this value. Under the environmentally sound planning scenario, the potential of the plain for regulating ecosystem services such as carbon storage and sequestration was higher than the business as usual scenario. The downward carbon sequestration trend could be reversed under the environmentally sound planning scenario estimated to save $3,705,491 \mathrm{Mg}$ in carbon storage, with an average sequestration gain of $+605,830 \mathrm{Mg}$. Under the business as usual scenario, loss of stored carbon could be $(2,624,113 \mathrm{Mg})$ with an average sequestration loss of $-475,547 \mathrm{Mg}$. Therefore, the areas with a high potential of losing carbon storage under the business as usual scenario (i.e., expanding agricultural and urban land cover) and gaining carbon sequestration under the environmentally sound planning scenario (i.e., forests) must exclusively be protected during the development of future land use/cover change policies. This ensemble of results could provide an integrated dynamic framework to the authorities for developing a systematic decision-making process by considering the spatiotemporal change on carbon storage and sequestration. This integrated process considers a combination of several criteria (e.g., environmental protection, sustainable agriculture, controlled development) and could be applied to similar dryland ecosystems regarding their planning and management.
Supplementary Information The online version contains supplementary material available at https://doi.org/10.1007/s13762-021-03676-6.

Acknowledgements The authors would like to thank the support provided by the Iran National Science Foundation (grant number: 98012044), the National Natural Science Foundation of China, grant number 41861134038 and Eawag (Academic Transition Grant).

Author Contribution FA contributed to conceptualization, methodology, software, writing - original draft preparation. WZ contributed to data curation, reviewing, and editing. RC contributed to reviewing and editing. PM contributed to data curation and reviewing. TM helped in reviewing and editing. JSS contributed to supervision and validation.

Funding Open Access funding provided by Lib4RI - Library for the Research Institutes within the ETH Domain: Eawag, Empa, PSI \& WSL.

Open Access This article is licensed under a Creative Commons Attribution 4.0 International License, which permits use, sharing, adaptation, distribution and reproduction in any medium or format, as long as you give appropriate credit to the original author(s) and the source, provide a link to the Creative Commons licence, and indicate if changes were made. The images or other third party material in this article are included in the article's Creative Commons licence, unless indicated otherwise in a credit line to the material. If material is not included in the article's Creative Commons licence and your intended use is not permitted by statutory regulation or exceeds the permitted use, you will need to obtain permission directly from the copyright holder. To view a copy of this licence, visit http://creativecommons.org/licenses/by/4.0/.

\section{References}

Aalde H, Gonzalez P, Gytarsky M, Krug T, Kurz WA, Lasco RD, Martino DL, McConkey BG, Ogle S, Paustian K (2006) Generic methodologies applicable to multiple land-use categories. IPCC guidelines for national greenhouse gas in, n.d

Abbaspour KC, Faramarzi M, Ghasemi SS, Yang H (2009) Assessing the impact of climate change on water resources in Iran. Water Resour Res. https://doi.org/10.1029/2008WR007615

Adelisardou F, Jafari HR, Malekmohammadi B, Minkina T, Zhao W, Karbassi A (2021) Impacts of land use and land cover change on the interactions among multiple soil-dependent ecosystem services (case study: Jiroft plain Iran). Environ Geochem Health 43(10):3977-3996. https://doi.org/10.1007/s10653-021-00875-5

Agricultural Organization of Jiroft County (2013) The situation, data Qual. Cultiv. Jiroft county. Kerman, Iran

Agricultural Organization of Jiroft County, 2017. situation, data Qual. Cultiv. Jiroft county. Kerman, Iran

Bagstad KJ, Semmens DJ, Winthrop R (2013) Comparing approaches to spatially explicit ecosystem service modeling: a case study from the San Pedro River. Arizona Ecosyst Serv 5:40-50. https:// doi.org/10.1016/j.ecoser.2013.07.007

Boix-Fayos C, de Vente J, Albaladejo J, Martínez-Mena M (2009) Soil carbon erosion and stock as affected by land use changes at the catchment scale in Mediterranean ecosystems. Agric Ecosyst Environ 133:75-85. https://doi.org/10.1016/j.agee.2009.05.013

Bren d'Amour C, Reitsma F, Baiocchi G, Barthel S, Güneralp B, Erb K-H, Haberl H, Creutzig F, Seto KC (2017) Future urban land expansion and implications for global croplands. Proc Natl Acad Sci 114:8939-8944. https://doi.org/10.1073/pnas.1606036114

Brovkin V, Boysen L, Arora VK, Boisier JP, Cadule P, Chini L, Claussen M, Friedlingstein P, Gayler V, van den Hurk BJJM, Hurtt GC, 
Jones CD, Kato E, de Noblet-Ducoudré N, Pacifico F, Pongratz J, Weiss M (2013) Effect of anthropogenic land-use and land-cover changes on climate and land carbon storage in CMIP5 projections for the Twenty-First Century. J Clim 26:6859-6881. https://doi. org/10.1175/JCLI-D-12-00623.1

Canadell JG, Raupach MR (2008) Managing forests for climate change mitigation. Science 320:1456-1457. https://doi.org/10.1126/ science. 1155458

Cassidy L, Binford M, Southworth J, Barnes G (2010) Social and ecological factors and land-use land-cover diversity in two provinces in southeast Asia. J Land Use Sci 5:277-306. https://doi.org/10. 1080/1747423X.2010.500688

Ceschia E, Béziat P, Dejoux JF, Aubinet M, Bernhofer C, Bodson B, Buchmann N, Carrara A, Cellier P, Di Tommasi P, Elbers JA, Eugster W, Grünwald T, Jacobs CMJ, Jans WWP, Jones M, Kutsch W, Lanigan G, Magliulo E, Marloie O, Moors EJ, Moureaux C, Olioso A, Osborne B, Sanz MJ, Saunders M, Smith P, Soegaard H, Wattenbach M (2010) Management effects on net ecosystem carbon and GHG budgets at European crop sites. Agric Ecosyst Environ 139:363-383. https://doi.org/10.1016/j. agee.2010.09.020

Cheng X, Yang Y, Li M, Dou X, Zhang Q (2013) The impact of agricultural land use changes on soil organic carbon dynamics in the Danjiangkou Reservoir area of China. Plant Soil 366:415-424. https://doi.org/10.1007/s11104-012-1446-6

Chuai X, Huang X, Lai L, Wang W, Peng J, Zhao R (2013) Land use structure optimization based on carbon storage in several regional terrestrial ecosystems across China. Environ Sci Policy 25:50-61. https://doi.org/10.1016/j.envsci.2012.05.005

Congalton RG (1991) A review of assessing the accuracy of classifications of remotely sensed data. Remote Sens Environ 37:35-46. https://doi.org/10.1016/0034-4257(91)90048-B

Cordingley JE, Newton AC, Rose RJ, Clarke RT, Bullock JM (2016) Can landscape-scale approaches to conservation management resolve biodiversity-ecosystem service trade-offs? J Appl Ecol 53:96-105. https://doi.org/10.1111/1365-2664.12545

Crossman ND, Burkhard B, Nedkov S, Willemen L, Petz K, Palomo I, Drakou EG, Martín-Lopez B, McPhearson T, Boyanova K, Alkemade R, Egoh B, Dunbar MB, Maes J (2013) A blueprint for mapping and modelling ecosystem services. Ecosyst Serv 4:4-14. https://doi.org/10.1016/j.ecoser.2013.02.001

de Groot R, Brander L, van der Ploeg S, Costanza R, Bernard F, Braat L, Christie M, Crossman N, Ghermandi A, Hein L, Hussain S, Kumar P, McVittie A, Portela R, Rodriguez LC, ten Brink P, van Beukering P (2012) Global estimates of the value of ecosystems and their services in monetary units. Ecosyst Serv 1:50-61. https://doi.org/10.1016/j.ecoser.2012.07.005

Eggleston H, Buendia L, Miwa K, Ngara T, Tanabe K (2006) IPCC guidelines for national greenhouse gas inventories. Institute for Global Environmental Strategies, Hayama, Japan

Egoh B, Bengtsson J, Lindborg R, Bullock J, Dixon A, Rouget M (2016) The importance of grasslands in providing ecosystem services: opportunities for poverty alleviation. In: Potschin M, Haines-Young R, Fish R, Turner RK (eds) Routledge Handbook of Ecosystem Services. Routledge, London and New York, pp 978-113802

Egoh BN, Reyers B, Rouget M, Richardson DM (2011) Identifying priority areas for ecosystem service management in South African grasslands. J Environ Manage 92:1642-1650. https://doi.org/10. 1016/j.jenvman.2011.01.019

Favretto N, Stringer LC, Dougill AJ, Dallimer M, Perkins JS, Reed MS, Atlhopheng JR, Mulale K (2016) Multi-Criteria decision analysis to identify dryland ecosystem service trade-offs under different rangeland land uses. Ecosyst Serv 17:142-151. https://doi.org/ 10.1016/j.ecoser.2015.12.005
Fleurbaey M, Ferranna M, Budolfson M, Dennig F, Mintz-Woo K, Socolow R, Spears D, Zuber S (2019) The social cost of carbon: valuing inequality, risk, and population for climate policy. Monist 102:84-109. https://doi.org/10.1093/monist/ony023

Fu Q, Li B, Hou Y, Bi X, Zhang X (2017) Effects of land use and climate change on ecosystem services in Central Asia's arid regions: a case study in Altay Prefecture. China Sci Total Environ 607-608:633-646. https://doi.org/10.1016/j.scitotenv.2017. 06.241

Gallant K, Withey P, Risk D, van Kooten GC, Spafford L (2020) Measurement and economic valuation of carbon sequestration in Nova Scotian wetlands. Ecol Econ 171:106619. https://doi. org/10.1016/j.ecolecon.2020.106619

Ghosh P, Mukhopadhyay A, Chanda A, Mondal P, Akhand A, Mukherjee S, Nayak SK, Ghosh S, Mitra D, Ghosh T, Hazra S (2017) Application of cellular automata and Markov-chain model in geospatial environmental modeling- A review. Remote Sens Appl Soc Environ 5:64-77. https://doi.org/10.1016/j.rsase.2017. 01.005

Gibbs HK, Brown S, Niles JO, Foley JA (2007) Monitoring and estimating tropical forest carbon stocks: making REDD a reality. Environ Res Lett 2:045023. https://doi.org/10.1088/1748-9326/2/ 4/045023

Google Earth (2015) Retrieved March 10, 2016, n.d. No Title

Google Earth Engine (2012) Retrieved February 5, 2014, from https: //earthengine. google. co., n.d. -

Grinand C, Maire GL, Vieilledent G, Razakamanarivo H, Razafimbelo T, Bernoux M (2017) Estimating temporal changes in soil carbon stocks at ecoregional scale in Madagascar using remote-sensing. Int J Appl Earth Obs Geoinf 54:1-14. https://doi.org/10.1016/j. jag.2016.09.002

Haight RG, Bluffstone R, Kline JD, Coulston JW, Wear DN, Zook K (2020) Estimating the present value of carbon sequestration in U.S. forests, 2015-2050, for evaluating federal climate change mitigation policies. Agric Resour Econ Rev 49:150-177. https:// doi.org/10.1017/age.2019.20

Hamad R, Balzter H, Kolo K (2018) Predicting land use/land cover changes using a CA-Markov model under two different scenarios. Sustainability 10:3421. https://doi.org/10.3390/su10103421

Hauck J, Görg C, Varjopuro R, Ratamäki O, Maes J, Wittmer H, Jax K (2013) "Maps have an air of authority": Potential benefits and challenges of ecosystem service maps at different levels of decision making. Ecosyst Serv 4:25-32. https://doi.org/10.1016/j. ecoser.2012.11.003

He C, Zhang D, Huang Q, Zhao Y (2016) Assessing the potential impacts of urban expansion on regional carbon storage by linking the LUSD-urban and InVEST models. Environ Model Softw 75:44-58. https://doi.org/10.1016/j.envsoft.2015.09.015

IPCC IPCC special report on carbon dioxide capture and storage (2005) Cambridge University Press, U. K

IPCC Guidelines for National Greenhouse Gas Inventories (2006) Available at: http://www.ipcc-nggip.iges.or.jp/public/2006gl/ index.html

IPCC Special Report on Carbon Dioxide Capture and Storage (2005) Cambridge Univ Press. Cambridge

IPCC Special Report on Land Use Land-Use Change and Forestry (2000) Cambridge University Press, Cambridge

Iran statistical Yearbook (2017) Statistical Yearbook of Iran. Iranian Statistics Press, Tehran., n.d

Jiang W, Deng Y, Tang Z, Lei X, Chen Z (2017) Modelling the potential impacts of urban ecosystem changes on carbon storage under different scenarios by linking the CLUE-S and the InVEST models. Ecol Modell 345:30-40. https://doi.org/10.1016/j.ecolmodel. 2016.12.002

Jiroft Municipal Statistics Bureau (2017) Stat. Yearb. Jiroft 1995-2017. Agric. Jahad Organ. Jiroft. Iran 
Kanianska R (2016) Agriculture and Its Impact on Land-Use, Environment, and Ecosystem Services, in: Landscape Ecology - The Influences of Land Use and Anthropogenic Impacts of Landscape Creation. InTech. https://doi.org/10.5772/63719

Kanime N, Kaushal R, Tewari SK, Raverkar KP, Chaturvedi S, Chaturvedi OP (2013) Biomass production and carbon sequestration in different tree-based systems of Central Himalayan Tarai region. For Trees Livelihoods 22:38-50. https://doi.org/10.1080/14728 028.2013.764073

Kavzoglu T, Colkesen I (2009) A kernel functions analysis for support vector machines for land cover classification. Int J Appl Earth Obs Geoinf 11:352-359. https://doi.org/10.1016/j.jag.2009.06. 002

Keller AA, Fournier E, Fox J (2015) Minimizing impacts of land use change on ecosystem services using multi-criteria heuristic analysis. J Environ Manage 156:23-30. https://doi.org/10.1016/j. jenvman.2015.03.017

Kerman Municipal Statistics Bureau (2015) Stat. Yearb. Kerman 19982015. Agric. Jahad Organ. Kerman. Iran

Kerman Municipal Statistics Bureau (2018) Stat. Yearb. Kerman 19982015. Agric. Jahad Organ. Kerman. Iran

Leh MDK, Matlock MD, Cummings EC, Nalley LL (2013) Quantifying and mapping multiple ecosystem services change in West Africa. Agric Ecosyst Environ 165:6-18. https://doi.org/10. 1016/j.agee.2012.12.001

Li L, Song Y, Wei X, Dong J (2020) Exploring the impacts of urban growth on carbon storage under integrated spatial regulation: a case study of Wuhan. China Ecol Indic 111:106064. https://doi. org/10.1016/j.ecolind.2020.106064

Liang Y, Liu L, Huang J (2017) Integrating the SD-CLUE-S and InVEST models into assessment of oasis carbon storage in northwestern China. PLoS ONE 12:e0172494. https://doi.org/10.1371/ journal.pone. 0172494

Lininger KB, Wohl E, Rose JR, Leisz SJ (2019) Significant floodplain soil organic carbon storage along a large High-Latitude River and its tributaries. Geophys Res Lett 46:2121-2129. https://doi.org/ 10.1029/2018GL080996

Liping C, Yujun S, Saeed S (2018) Monitoring and predicting land use and land cover changes using remote sensing and GIS techniques-A case study of a hilly area, Jiangle. China Plos One 13:e0200493. https://doi.org/10.1371/journal.pone.0200493

Lu N, Wang M, Ning B, Yu D, Fu B (2018) Research advances in ecosystem services in drylands under global environmental changes. Curr Opin Environ Sustain 33:92-98. https://doi.org/10.1016/j. cosust.2018.05.004

Lü Y, Ma Z, Zhao Z, Sun F, Fu B (2014) Effects of land use change on soil carbon storage and water consumption in an Oasis-Desert ecotone. Environ Manage 53:1066-1076. https://doi.org/10. 1007/s00267-014-0262-6

Luo T, Xu M, Wang Z, Yu Z (2019) A comparative study on the performance of three color schemes in landscape preference tests. J Environ Eng Landsc Manag 27:114-125. https://doi.org/10. 3846/jeelm.2019.9805

MA (2005) Millennium Ecosystem Assessment. Ecosyst. Hum. WellBeing Curr. State Trends, Press. Washington, DC

Maes J, Liquete C, Teller A, Erhard M, Paracchini ML, Barredo JI, Grizzetti B, Cardoso A, Somma F, Petersen J-E, Meiner A, Gelabert ER, Zal N, Kristensen P, Bastrup-Birk A, Biala K, Piroddi C, Egoh B, Degeorges P, Fiorina C, Santos-Martín F, Naruševičius V, Verboven J, Pereira HM, Bengtsson J, Gocheva K, MartaPedroso C, Snäll T, Estreguil C, San-Miguel-Ayanz J, Pérez-Soba M, Grêt-Regamey A, Lillebø AI, Malak DA, Condé S, Moen J, Czúcz B, Drakou EG, Zulian G, Lavalle C (2016) An indicator framework for assessing ecosystem services in support of the EU Biodiversity Strategy to 2020. Ecosyst Serv 17:14-23. https:// doi.org/10.1016/j.ecoser.2015.10.023
Maestre FT, Eldridge DJ, Soliveres S, Kéfi S, Delgado-Baquerizo M, Bowker MA, García-Palacios P, Gaitán J, Gallardo A, Lázaro R, Berdugo M (2016) Structure and functioning of dryland ecosystems in a changing world. Annu Rev Ecol Evol Syst 47:215-237. https://doi.org/10.1146/annurev-ecolsys-121415-032311

Mahowald NM, Randerson JT, Lindsay K, Munoz E, Doney SC, Lawrence P, Schlunegger S, Ward DS, Lawrence D, Hoffman FM (2017) Interactions between land use change and carbon cycle feedbacks. Global Biogeochem Cycles 31:96-113. https://doi. org/10.1002/2016GB005374

Malczewski J (1999) GIS and multicriteria decision analysis. Wiley, New York

Mansouri Daneshvar MR, Ebrahimi M, Nejadsoleymani H (2019) An overview of climate change in Iran: facts and statistics. Environ Syst Res 8:7. https://doi.org/10.1186/s40068-019-0135-3

Mazaheri M, Esfandiari M, Masihabadi MH, Kamali A (2013) Detecting temporal land use changes using remote sensing and GIS techniqes (Case study: Jiroft, Kerman Province). J. Appl. RS GIS Tech. Nat. Resour. Sci. 4. http: //isj.iup.ir/index. aspx ?pid $=95744 \&$ jid $=186$

Melaku Canu D, Ghermandi A, Nunes PALD, Lazzari P, Cossarini G, Solidoro C (2015) Estimating the value of carbon sequestration ecosystem services in the Mediterranean Sea: an ecological economics approach. Glob Environ Chang 32:87-95. https://doi. org/10.1016/j.gloenvcha.2015.02.008

Nonini L, Fiala M (2019) Estimation of carbon storage of forest biomass for voluntary carbon markets: preliminary results. J For Res. https://doi.org/10.1007/s11676-019-01074-w

Nordhaus W (2007) Economics: critical assumptions in the stern review on climate change. Science 317:201-202. https://doi.org/ 10.1126/science. 1137316

Ontl TA, Janowiak MK, Swanston CW, Daley J, Handler S, Cornett M, Hagenbuch S, Handrick C, Mccarthy L, Patch N (2020) Forest management for carbon sequestration and climate adaptation. $\mathrm{J}$ for 118:86-101. https://doi.org/10.1093/jofore/fvz062

Padilla FM, Vidal B, Sánchez J, Pugnaire FI (2010) Land-use changes and carbon sequestration through the twentieth century in a Mediterranean mountain ecosystem: implications for land management. J Environ Manage 91:2688-2695. https://doi.org/10. 1016/j.jenvman.2010.07.031

Poeplau C, Don A (2013) Sensitivity of soil organic carbon stocks and fractions to different land-use changes across Europe. Geoderma 192:189-201. https://doi.org/10.1016/j.geoderma.2012.08.003

Polasky S, Nelson E, Pennington D, Johnson KA (2011) The impact of land-use change on ecosystem services, biodiversity and returns to landowners: a case study in the state of Minnesota. Environ Resour Econ 48:219-242. https://doi.org/10.1007/ s10640-010-9407-0

Pontius R, Gao Y, Giner N, Kohyama T, Osaki M, Hirose K (2013) Design and interpretation of intensity analysis illustrated by land change in Central Kalimantan, Indonesia. Land 2:351-369. https://doi.org/10.3390/land2030351

Rahbarian P, Sardoei AS (2014) Effects of drought stress and manure on dry herb yield and essential oil of Dragonhead Dracocphalum moldavica in Jiroft erea. Int J Biosci. https://doi.org/10.12692/ ijb/4.9.212-217

Reddy CS, Singh S, Dadhwal VK, Jha CS, Rao NR, Diwakar PG (2017) Predictive modelling of the spatial pattern of past and future forest cover changes in India. J Earth Syst Sci 126:8. https://doi.org/10.1007/s12040-016-0786-7

Redhead JW, Stratford C, Sharps K, Jones L, Ziv G, Clarke D, Oliver TH, Bullock JM (2016) Empirical validation of the InVEST water yield ecosystem service model at a national scale. Sci Total Environ 569-570:1418-1426. https://doi.org/10.1016/j.scitotenv. 2016.06.227 
Regmi RR, Saha SK, Subedi DS (2017) Geospatial analysis of land use land cover change modeling in Phewa Lake Watershed of Nepal by using GEOMOD model. Himal Phys. https://doi.org/ 10.3126/hj.v6i0.18363

Samie A, Deng X, Jia S, Chen D (2017) Scenario-based simulation on dynamics of land-use-land-cover change in Punjab Province. Pak Sustain 9:1285. https://doi.org/10.3390/su9081285

Sánchez-Canales M, López Benito A, Passuello A, Terrado M, Ziv G, Acuña V, Schuhmacher M, Elorza FJ (2012) Sensitivity analysis of ecosystem service valuation in a Mediterranean watershed. Sci Total Environ 440:140-153. https://doi.org/10.1016/j.scito tenv.2012.07.071

Sandker M, Campbell BM, Ruiz-Pérez M, Sayer JA, Cowling R, Kassa H, Knight AT (2010) The role of participatory modeling in landscape approaches to reconcile conservation and development. Ecol Soc. https://doi.org/10.5751/ES-03400-150213

Sang X, Guo Q, Wu X, Fu Y, Xie T, He C, Zang J (2019) Intensity and stationarity analysis of land use change based on CART algorithm. Sci Rep 9:12279. https://doi.org/10.1038/ s41598-019-48586-3

Sanjari S (2015) Evaluation of Land Use Change Trends in Jiroft Plain Using Remote Sensing Technique. First Sci. Congr. Dev. Promot. Agric. Sci. Nat. Resour. Environ. Iran, Tehran.(In Farsi)

Sayer JA, Margules C, Boedhihartono AK, Sunderland T, Langston JD, Reed J, Riggs R, Buck LE, Campbell BM, Kusters K, Elliott C, Minang PA, Dale A, Purnomo H, Stevenson JR, Gunarso P, Purnomo A (2017) Measuring the effectiveness of landscape approaches to conservation and development. Sustain Sci 12:465-476. https://doi.org/10.1007/s11625-016-0415-z

Scandellari F, Caruso G, Liguori G, Meggio F, Palese Assunta M, Zanotelli D, Celano G, Gucci R, Inglese P, Pitacco A, Tagliavini M (2016) A survey of carbon sequestration potential of orchards and vineyards in Italy. Eur J Hortic Sci 81:106-114. https://doi. org/10.17660/eJHS.2016/81.2.4

Shangguan W, Dai Y, Duan Q, Liu B, Yuan H (2014) A global soil data set for earth system modeling. J Adv Model Earth Syst 6:249-263. https://doi.org/10.1002/2013MS000293

Sharp R, Tallis HT, Ricketts T, Guerry AD, Wood SA, Chaplin-Kramer R, Vigerstol K (2020) InVEST user's guide. The Natural Capital Project, Stanford

Sidhu N, Pebesma E, Câmara G (2018) Using Google Earth Engine to detect land cover change: Singapore as a use case. Eur J Remote Sens 51:486-500. https://doi.org/10.1080/22797254.2018.14517 82

Sil Â, Fonseca F, Gonçalves J, Honrado J, Marta-Pedroso C, Alonso J, Ramos M, Azevedo JC (2017) Analysing carbon sequestration and storage dynamics in a changing mountain landscape in Portugal: insights for management and planning. Int J Biodivers Sci Ecosyst Serv Manag 13:82-104. https://doi.org/10.1080/21513 732.2017.1297331

Singh SK, Mustak S, Srivastava PK, Szabó S, Islam T (2015) Predicting spatial and decadal LULC changes through cellular automata Markov Chain Models using earth observation datasets and geoinformation. Environ Process 2:61-78. https://doi.org/10.1007/ s40710-015-0062-x

Socolow RH (2005) Can we bury global warming? Sci Am 293:49-55. https://doi.org/10.1038/scientificamerican0705-49

Socolow RH, Pacala SW (2006) A plan to keep carbon in check. Sci Am 295:50-57. https://doi.org/10.1038/scientificamerican09 06-50

Stehman SV (1997) Selecting and interpreting measures of thematic classification accuracy. Remote Sens Environ 62:77-89. https:// doi.org/10.1016/S0034-4257(97)00083-7

Stern N (2007) The economics of climate change. Cambridge University Press, Cambridge. https://doi.org/10.1017/CBO9780511 817434
Stringer LC, Dougill AJ, Thomas AD, Spracklen DV, Chesterman S, Speranza CI, Rueff H, Riddell M, Williams M, Beedy T, Abson DJ, Klintenberg P, Syampungani S, Powell P, Palmer AR, Seely MK, Mkwambisi DD, Falcao M, Sitoe A, Ross S, Kopolo G (2012) Challenges and opportunities in linking carbon sequestration, livelihoods and ecosystem service provision in drylands. Environ Sci Policy 19-20:121-135. https://doi.org/10.1016/j. envsci.2012.02.004

Tallis HT, Ricketts T, Guerry AD, Wood SA, Sharp R, Nelson E, Pennington D (2013) Capital Project: Stanford. InVEST 2.5. 6 user's Guid. Nat. Cap. Proj. Stanford, CA, USA

Teixeira Z, Marques JC, Pontius RG (2016) Evidence for deviations from uniform changes in a Portuguese watershed illustrated by CORINE maps: an Intensity Analysis approach. Ecol Indic 66:382-390. https://doi.org/10.1016/j.ecolind.2016.01.018

UN-REDD Programme, 2008. . https://www.un-redd.org/

UNDP and climate change (2015) Available from https//www.undp. org/content/undp/en/home/librarypage/climate-and-disaster-resil ience-/undp-and-climate-change.html.

Wang S, Wang Q, Adhikari K, Jia S, Jin X, Liu H (2016) SpatialTemporal changes of soil organic carbon content in Wafangdian. China Sustainability 8:1154. https://doi.org/10.3390/su8111154

Wang X, Qie S (2018) When to invest in carbon capture and storage: a perspective of supply chain. Comput Ind Eng 123:26-32. https:// doi.org/10.1016/j.cie.2018.06.006

White RP, Nackoney J (2003) Drylands, people and ecosystem goods and services: a web-based geospatial analysis. World Resources Institute, Washington, D.C., USA

Wu H, Li Z, Clarke KC, Shi W, Fang L, Lin A, Zhou J (2019) Examining the sensitivity of spatial scale in cellular automata Markov chain simulation of land use change. Int J Geogr Inf Sci 33:1040 1061. https://doi.org/10.1080/13658816.2019.1568441

Yang H, Huang J, Liu D (2020) Linking climate change and socioeconomic development to urban land use simulation: analysis of their concurrent effects on carbon storage. Appl Geogr 115:102135. https://doi.org/10.1016/j.apgeog.2019.102135

Yavari AR, Bahreini H (2001) Landuse planning, using simple capability zoning method. Environ Stud 27:124-132

Yirsaw E, Wu W, Shi X, Temesgen H, Bekele B (2017) Land use/ land cover change modeling and the prediction of subsequent changes in ecosystem service values in a coastal area of China, the Su-Xi-Chang region. Sustainability 9:1204. https://doi.org/ 10.3390/su9071204

Yuan K, Li F, Yang H, Wang Y (2019) The influence of land use change on ecosystem service value in Shangzhou District. Int J Environ Res Public Health 16:1321. https://doi.org/10.3390/ ijerph16081321

Zhang M, Huang X, Chuai X, Yang H, Lai L, Tan J (2015) Impact of land use type conversion on carbon storage in terrestrial ecosystems of China: a spatial-temporal perspective. Sci Rep 5:10233. https://doi.org/10.1038/srep10233

Zhao S, Tang Y, Chen A (2016) Carbon storage and sequestration of Urban Street trees in Beijing. China Front Ecol Evol. https://doi. org/10.3389/fevo.2016.00053

Zhao Z, Liu G, Mou N, Xie Y, Xu Z, Li Y (2018) Assessment of carbon storage and its influencing factors in Qinghai-Tibet plateau. Sustainability 10:1864. https://doi.org/10.3390/su10061864

Zhou D, Lin Z, Liu L (2012) Regional land salinization assessment and simulation through cellular automaton-Markov modeling and spatial pattern analysis. Sci Total Environ 439:260-274. https:// doi.org/10.1016/j.scitotenv.2012.09.013

Zhou P, Huang J, Pontius R, Hong H (2014) Land classification and change intensity analysis in a Coastal Watershed of Southeast China. Sensors 14:11640-11658. https://doi.org/10.3390/s1407 11640 